\title{
RUBBER AND ITS RELATIVES
}

(Reprint of an article from the Monthly Bulletin of the International Bureau of American Republics, December, 1908)

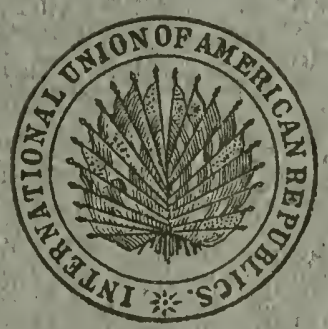

WASHINGTON, D. C. GOVERNMENT PRINTING OFFICE 
INTERNATIONAL BUREAU OF AMERICAN REPUBLICS JOHN BARRETT, DIRECTOR FRANCISCO J. YÁNES, SECRETARY

\section{RUBBER AND ITS RELATIVES}

(Reprint of an article from the Monthly Bulletin of the International Bureau of American Republics, December, 1908)

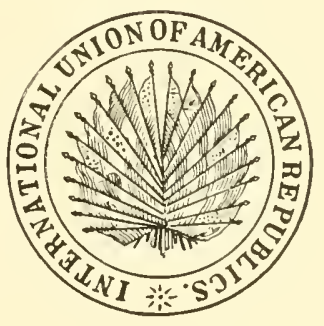

WASHINGTON, D. C.

GOVERNMENT PRINTING OFFICE 
gether so as to ejeet the liquid contents. This sulstance was called caucho in some parts of America and the gatherers were cancheros; in other parts the gatherer's were called, because of the shape of their

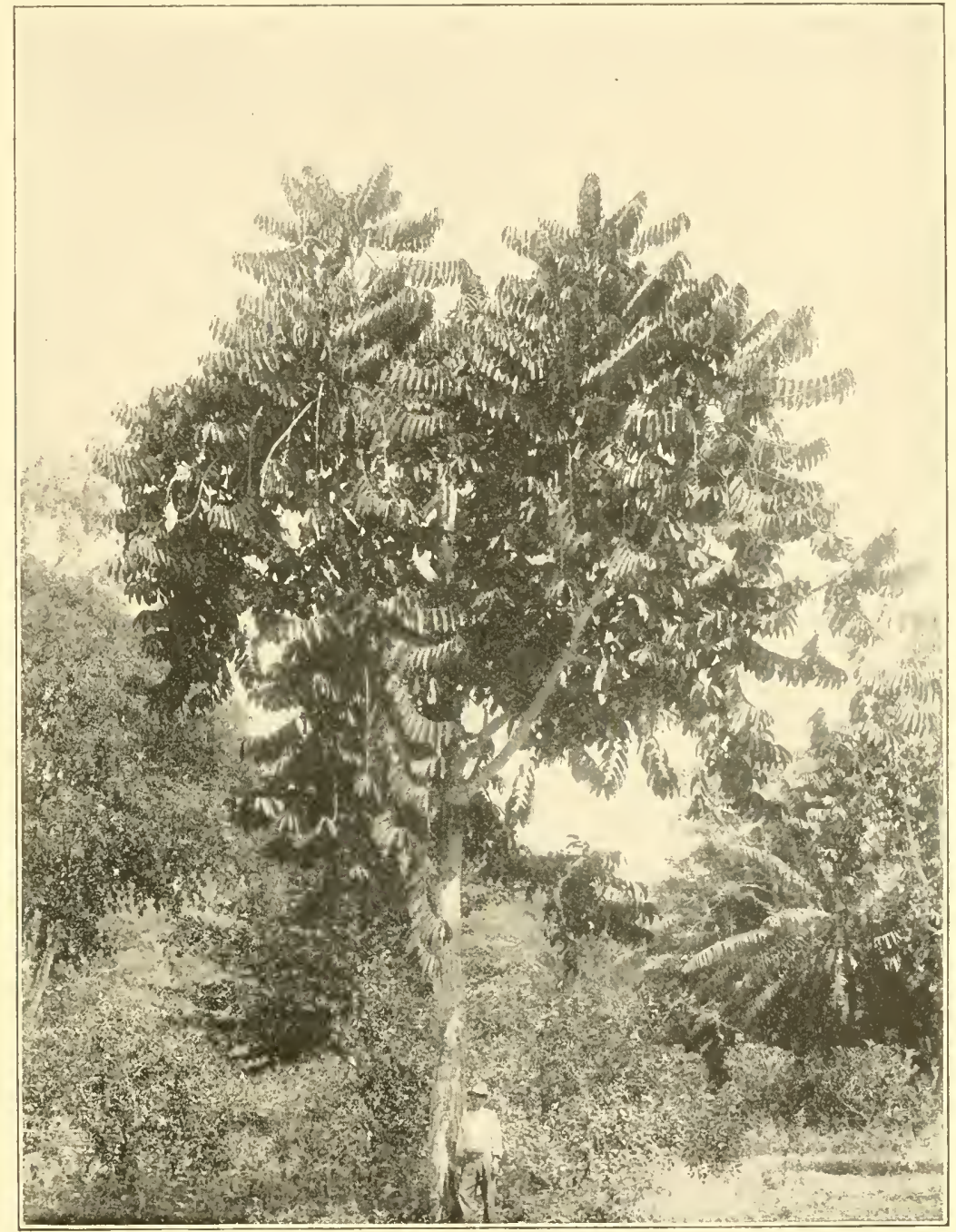

A liUBHEI TIEE OF THE CASTILLOA SPECIES.

This tree, like its relatives, the fig, breadfruit, and the trumpet tree, has a general appearanee and habit of growth which render it easy of recognition. The tree, with its rather smooth light-gray bark, has no striking peculiarities, but the slender, simple branches, with their large oval leaves, pendent in two rows, are similar to those of very few other trees. The Castilloa is native of 1 exieo and Central America, and thus far it has been supposed that its climatic and eultural requirements were quite different from those of the Para rubber tree, but it now appears that these differences have been greatly overestimated.

bottles and the uses to which the Portnguese saw them put, seringueiros, syringe men. From this origin the indiu prefix of the word 
is derived. It first the gum, goma elastica, according to the Spanish, was merely a curiosity: it was imported into Europe and studied chemically with great interest: it Hiss made into tubes and put to practical use in the laboratory. But in 1750 the English chemist Prinsmer recommended the use of the gum for effacing the marks of the lead pencil. It rubbed out these marks and was therefore a rubber. It became more widely known as experiment showed its value, and in 1823 Macistosm discovered the method of waterproof-

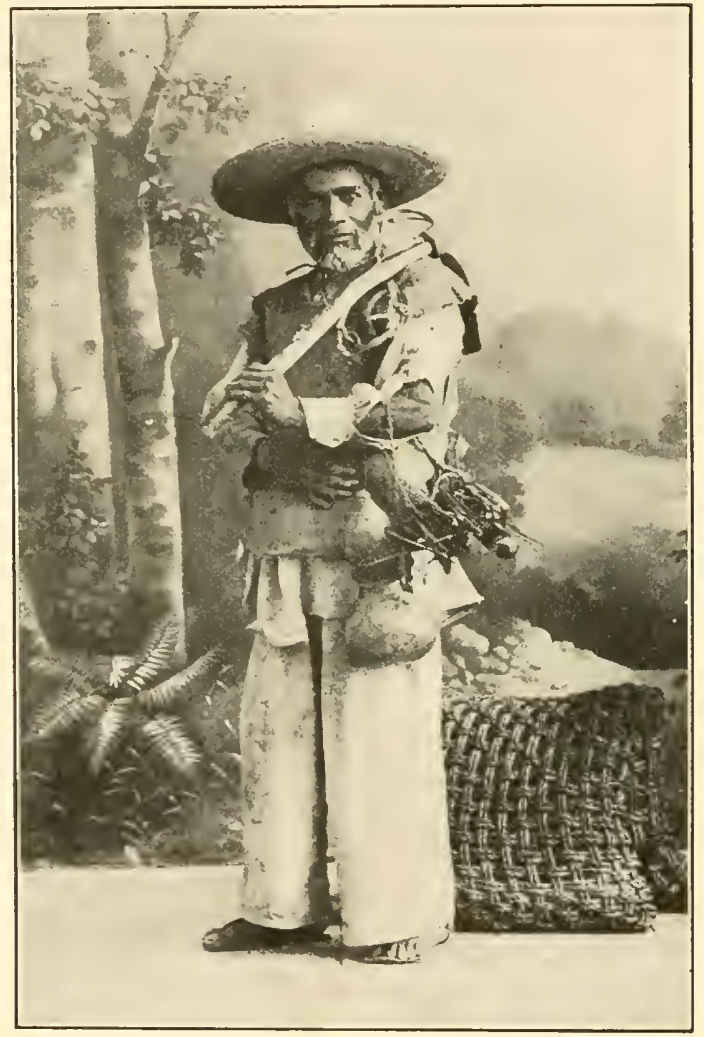

A RUBBER GATHERER IN TROPICAL MEXICO.

The "Ulero," or rubber gatherer, is provided with a sharp wedge-pointed ax for tapping the tree, and gourds for conveying the milk to be coagulated. He is generally assigned a given territory. A good collector will gather from 15 to 20 pounds of rubber per day.

ing garments, and added another word to the vocabulary. From this date india rubber was more and more an article of commerce; it served many puposes, but it also balked the inventors in many directions in which they had hoped it might be applied. Experiments were constantly being made; even the incorporation of sulphur had been tried, but it was not until 1839 that Nessox Goodrear, in the Lnited States, hit upon a practical methorl of combining rubber with 
sulphur so as to retain all its good. mique properties, while losing those that had made it hitherto unsuitable. 'This process was called vuleanization.

Rubber-india rubber-is a definite chemical combination of earbon and hydrogen, expressed by the (proportionate) formula $\mathrm{C}_{5} H_{s}$, or $\mathrm{C}_{10} \mathrm{II}_{16}$. It is a whitish solid, opaque, searcely reacted upon by the ordinary solvents, but forming fluid or gelatinons masses with the ethers and the coal-tar oils. All this refers, of course, to the chemically pure rubber. It will also melt and burn. Physically, rubber will stretch, and when tension is released its mass returns to the original position and form. Unfortmately, howerer, rubber in the pure state has three awkward qualities: It loses this distensibility at cer-

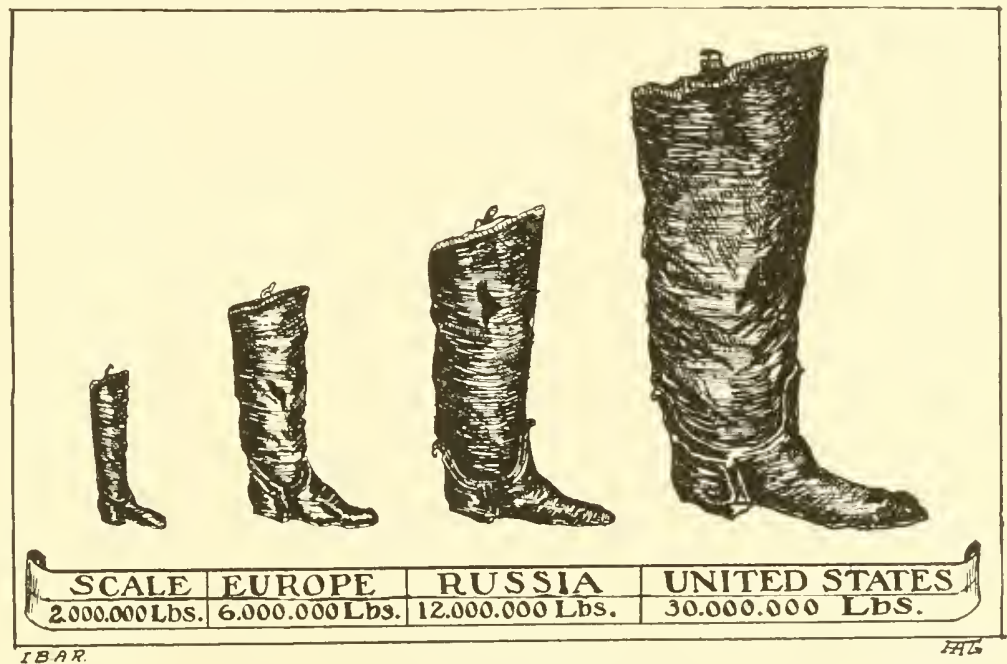

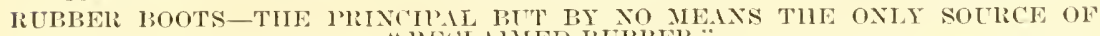

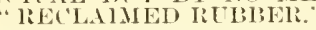

NотE.-Russia is not included in Europe, beeause it is attempted to show how great is the amount of rubber ( $\mathrm{rrom}$ boots and shoes) reclaimed in Russia alone, as contrasted with the remaining portion of Europe. The cut illustrates the amount of old rubber shoes now held in various parts of the world, waiting to be turned into " reclaimed rubber."

tain degrees of heat and cold. it softens under heat, and has a great tendency to stick to itself or to other masses of rubber with which it is brought in contact. Now, these three qualities of rubber as refined after entering the market from the tropical forests are orercome when it is mixed with sulphur-that is, vuleanized. It can then be molded into various shapes and still remain distensible. The degrees of temperature between which it retains these good qualities are very unch wider apart, so that elimatic changes are less felt by the manufactured product, and consequently rubber articles of an infinitely more varied type ean be turned ont from the factories. Vulcanized rubber is therefore the substance really implied ordinarily by the word alone. 


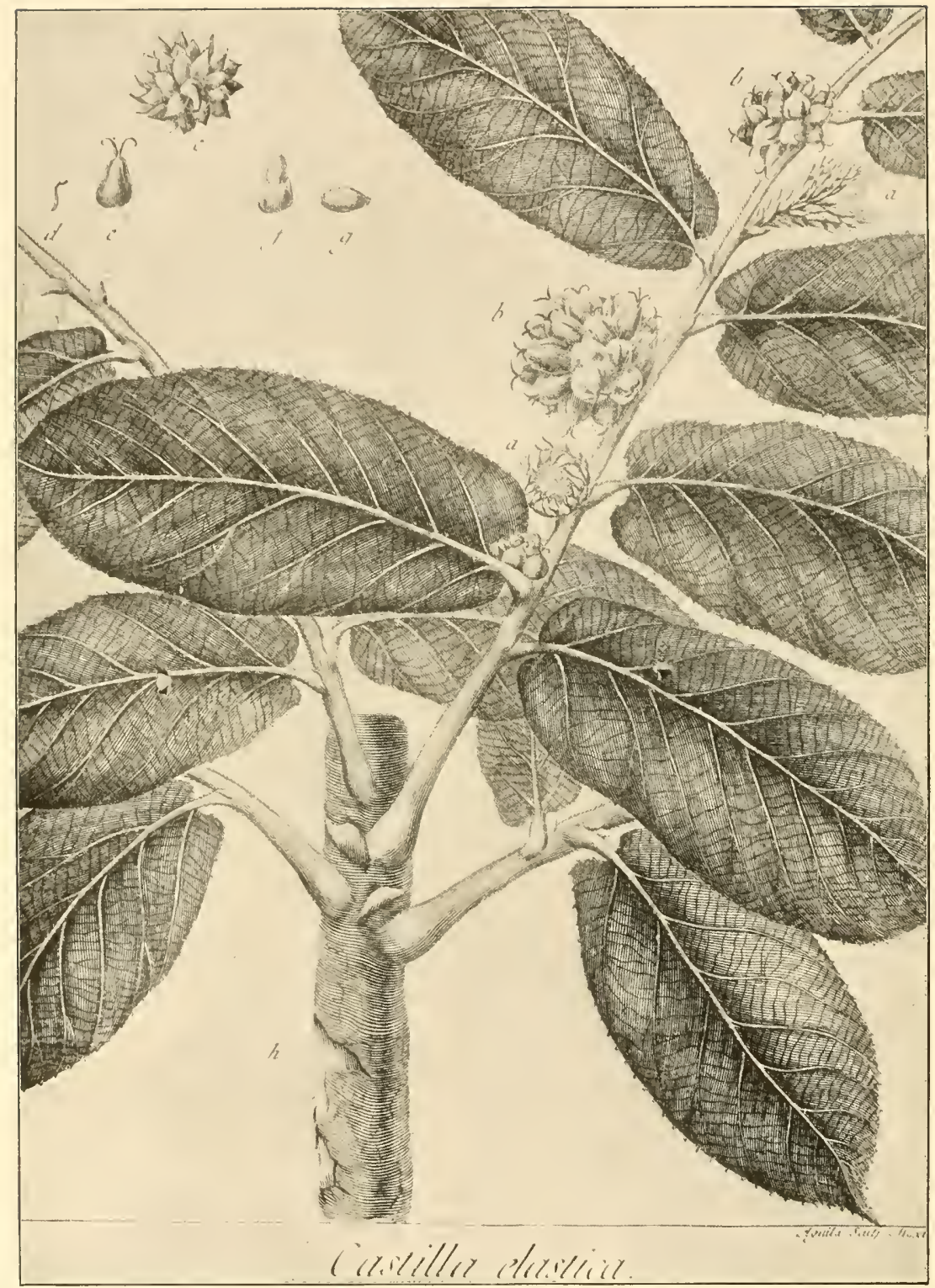

COPY OF THE ORIGINAL ENGRAVING OF THE CASTILLOA ELASTICA, SOMEWHAT REDUCED.

The rubber trees of Mexico received a botanical description and name in a paper read by Cervantes before the Royal Botanie Garden Ascor'iation of the city of Hexico in 1794, and was printed on an engraved plate, a copy of which is in the Library of Congress, Washington. The tree was named Castilla in honor of Castilla, a spranish botanist, who died in 1793, while engaged in the preparation of a work on the flora of Mexico. 
It might be thought that rubber would grow old after being once used in a manufactured article. So it does, but, almost like the metals, it has a new life when restored to its earlicr condition. Reclaimed rubber does not sell for as high a price as fresh rubber just imported, but it has a substantial value, and no discarded bit of rubber goods seems too old or worn-ont for reclamation and repeated use in the arts. Up to a short time ago old rubber shoes seemed to be the only

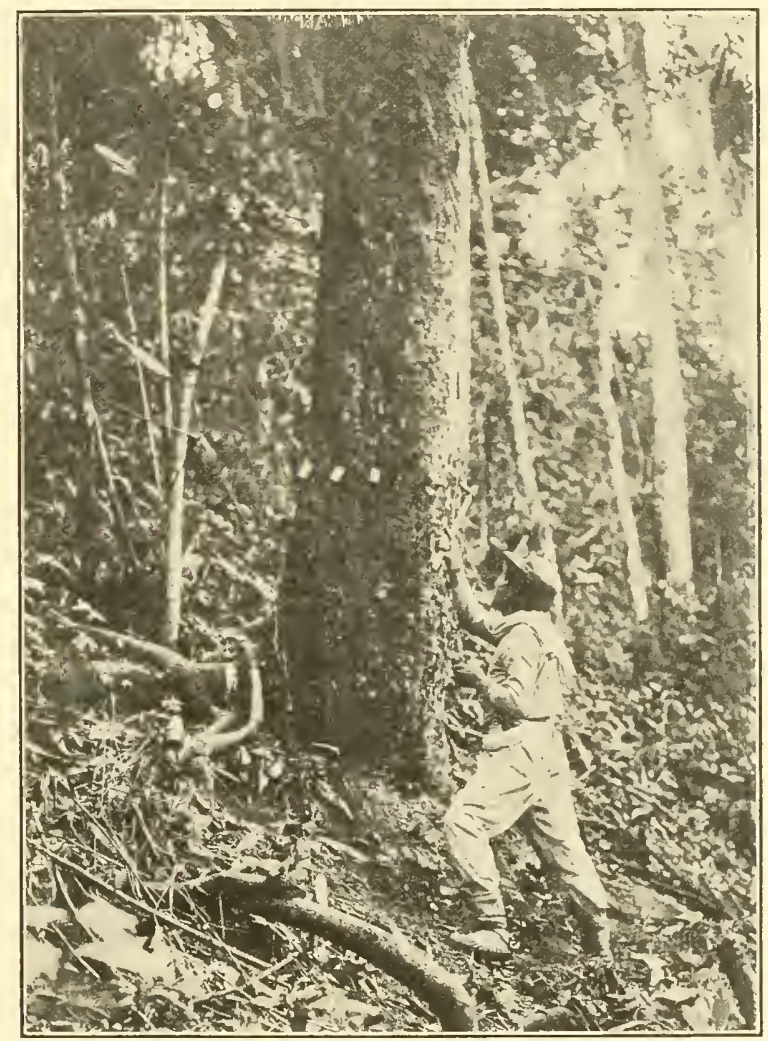

A RUBBER GATHERER IN BOLIVIA.

The tapping of the tree marks the beginning of the rubber gatherer's work. He attaches a small eup to the tree, and with a wedge-shaped ax makes a gash in the bark, being eareful not to penetrate the wood. This operation is repeated at intervals of about a foot in a line around the tree, until 5 or 6 cups have been plaeed, into which the milk flows slowly. The next day a row of ineisions is made just below the first, and so on until the ground is reaehed. A good treewill vield to a height of 20 feet or more. An expert gatherer can tap a hundred trees per day, provided they are close together.

or principal source of supply for reclaimed rubber, but to-day, thanks to modern ingenuity in devising chemical processes by which separation is accomplished, rubber is extracted from helts, from hose, or from the scrap of the trade, devulcanized as far as possible, and returned to the manufacturer for further use, although in this state it is never so generally serviceable as fresh rubber. The departments of government, the railway companies, and large users of rubber 
make a business of selling discarded articles, and rubber gatherers of the stuff rie with the eancheros in supplying the market with the results of their labor.

To one whose attention has not been carefully directed to the matter the multiplicity of the uses and combinations of rubber will be astonishing. All know how common are rubber bands, lead-pencil eraser tips, stamps. and fountain pens on a writing desk; every minute we see a wheeled rehicle fly past, its peace-destroying noise of

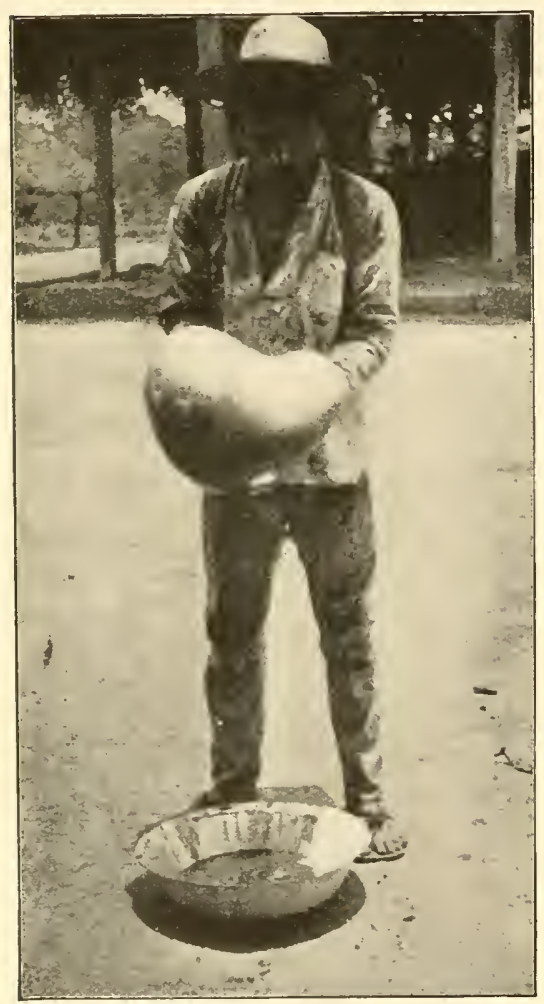

COAGULATING RUBBER BY THE TSE OF MOON VINE JUICE IN MEXICO.

The milk is emptied into this preparation, the impurities remainung in solution, and the elean rubber eollecting in a solid mass, which can be lifted off the top. yesterday obliterated by the rubber tire: but the use of rubber for these purposes, howerer enormous it is in the aggregate. by no means exhansts or even illustrates the demands for rubber in modern industry. The devices into which rubber enters can no more be enmmerated than can those of iron or copper, but among them may be mentioned the various appliances for insulation in electricity: withont rubber an entirely new method of telegraphing and telephoning wonld have to be invented. The air brake of the railroad must have rubber for its proper equipment: our fire service would be essentially crippled without rubber in the hose. and, in fact, hose of any kind can scarcely be conceived withont rnbber. Packing, belting, and tubing imply the nse of rubber. Then there are boots, rubber heels, and overshoes; coats and gloves for clothing: the many pharmacentical. dental, and surgical rubber goods, such as blankets. stopper's, combs. sheeting. bandages. water bottles, and syringes. In domestic life there are carpets, mats, toys, and cushions; rubber paint and pavement have special adrantages in selected places: roller skating would be a torment. and English tennis. Scotch golf, and American baseball wonld be decidedly tamer without rubber.

It is ericlent that there are two distinct phases to the study of this commercial commodity. The one is industrial, the other botanical. 
Before crude rubber becomes the finished product, it must be treated both mechanically and chemically to make it pliant for its multiform purposes. These processes are complicated. but necessary in transforming the raw material into an article rearly for manipulation into any of the shapes mentioned above. First the rubber must be washed and cut into bits, then it is squeezed between roller's in order to remove the water and to prepare it in sheets; then it is dried and made ready for compounding. Very few articles as employed today are made of the pure gum; some compound is necessary in many cases: in other's it is adopted in order to cheapen the price of the goods, which varies according to the quantity of compounded substance used. The consumer can, however, if he wishes to pay the cost, get the best possible article, the julgment of the manufacturer alone determining how much rubber to use.

Sulphur is the principal ingredient employed in rompounding rubber, and serves two purposes; it reduces the amount of pure rubber engaged for any article-in itself a raluable item-and it is the most efficient vulcanizer known. It transforms pure rubber into two distinct commercial substances, according to the amount of sulphur used. but chiefly according to the intensity of heat applied to effect the combination. for in all probability a chemical change occurs here. in addition to the undonbted physical union of rubber with sulphur. The one substance is soft

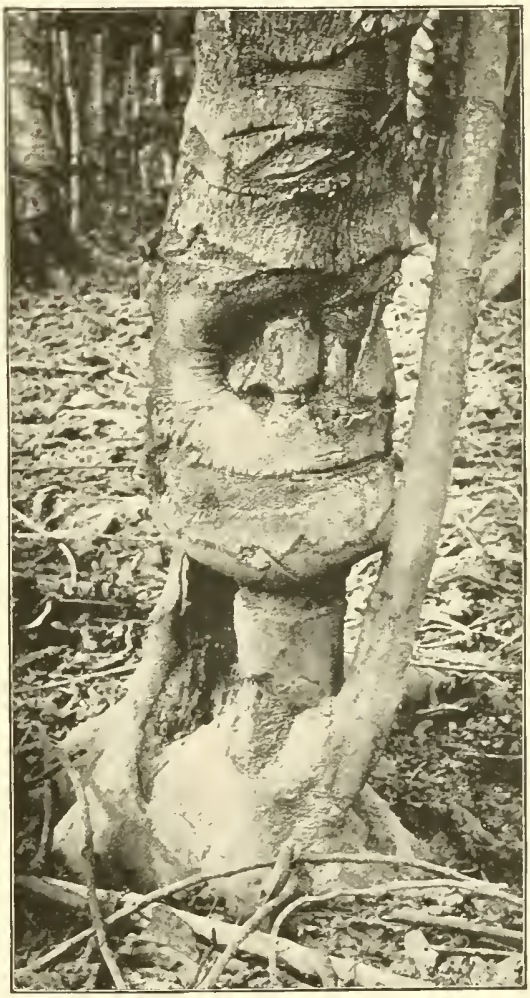

BASE OF TREE INJURED BY TAPPING.

Anxiety to obtain the largest rield of rubber, with sliglut rearard for the proteetion of the trees and for future produetion, has resulted in the permanent injury of many young trees rubber in the protean elastic condi-

tion familiar to all: this is produced by combining pure rubber with sulphur at a low temperature. The other substance is hard rubber, chonite, or vulcanite. in which all elasticity is lost. and the shape into which this is molded is permanently and rigidly retained, within natural temperature limits. Nerertheless, componnded and rulcanized rubber will not last forever: it grows brittle and dull with age, the gritty scales on the surface of combs, etc., being the crrstals of 
unabsorbed sulphur coming to the surface, so that rulcanized rubber must finally be desulphurized and returned to the trade as reclaimed rubber.

Millions have dreamed of the possibilities and fortumes have been premised as the result of a process producing a rubber substitute. Artificial or synthetic rubber would seem so easy ; take only ten atoms of arrbon and combine them with only sixteen atoms of hydrogen and you have rubber. But the little trick of adding life to this inert molecule has not yet been learned. The fortume is still there for the lucky inventor who can accomplish it, becanse carbon and hydrogen

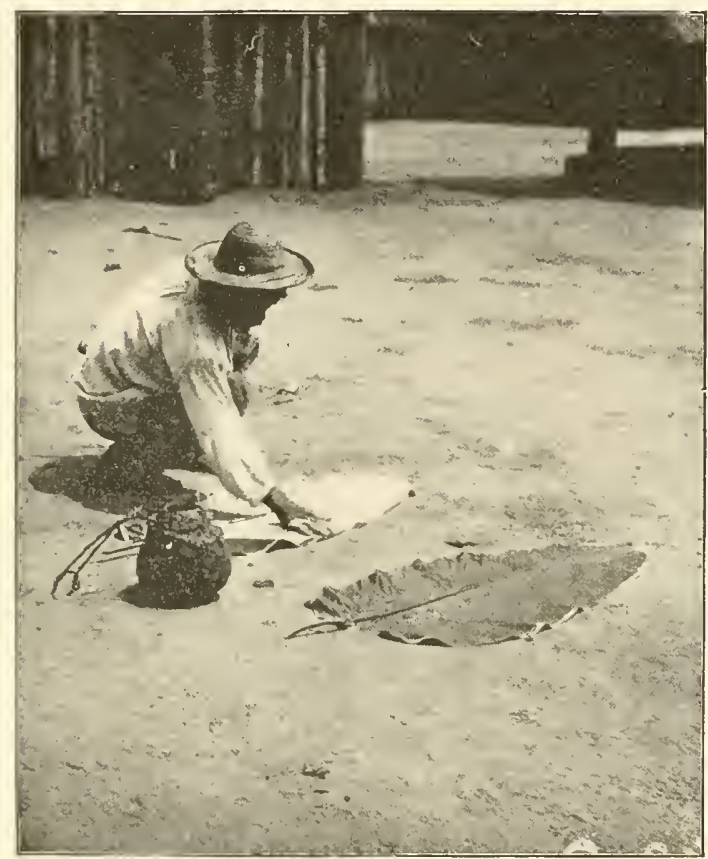

1

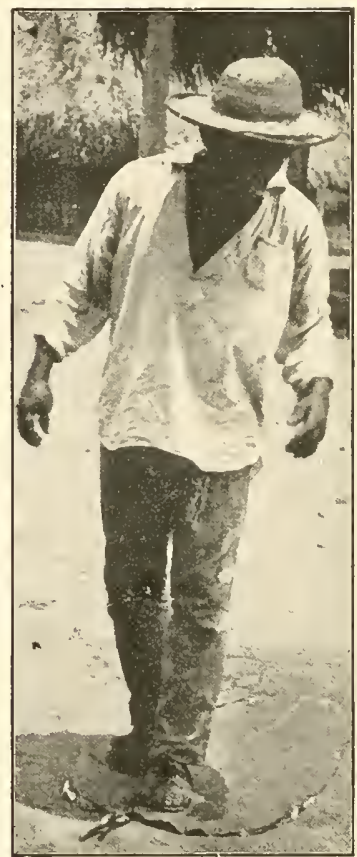

2

COAGULATING THE LATEX IN MEXICO.

1. Spreading the latex on Calathaea leaves. 2. Pressing the two coated leaves together to unite the sheets of rubber.

are cheap, inexhaustible eren, while rubber may get costlier year by year. The discussion of artificial rubber may therefore be dismissed with a phrase-there is no such thing. Either the exploited article is a humbug, or it contains some proportion of real rubber mixed with substitute ingredients. Rubber substitutes are often of value in the trade because the article manufactured from them only needs that small proportion of rubber they contain.

The botanical aspects of rubber are, however, the more fascinating to the investigator. and touch very much more intimately the field in which the International Bureau of the American Republics is 
interested. The plant from which the product comes is peculiarly a part of tropical flora, and although there are rubber-producing plants outside of tropical forests, the bulk of the staple is derired from a narrow belt on both sides of the equator, and decidedly better adapted in Latin Imerica to rubber growth than corresponding regions elsewhere.

Riubber is the cream from the juice, the milk, or the latex, of several varieties of tree or shrub. This latex is not the same as the sap, and it runs in different channels and performs different functions. As this latex flows from the ent in the tree, it has the appearance of milk and acts much in the same way. If left to itself, the latex separates into a lower fluid and a surface mass, like creaun, which is india rubber. A latex possessing from 15 to 40 per cent of rubber (cream) is of ralue and will pay for working. but a proportion below this is poor and thin, and only in exceptional cireumstances will it return any profit. Yarious ways have been dereloped or devised for obtaining this rubber from the latex, the process being intrinsically coagulation. The aboriginal method seems to have been, in Brazil, by smoking heat; elsewhere natural heat is applied, or mineral or chemical additions are made to the milk to separate the rubber. Recently the suggestion has been carried into practice of using the separator apparatus so eflicient in the dairy industry. It can not be doubted but that the coagulation process adlopted has a noticeable influence on the character and market price of crude rubber, although the lind of tree from which the latex flows, as well as the soil in which it grows, are substantial factors in the result. Having been, up to within recent times. largely a matter of native habit, left altogether in unscientific hands by the buyers of rubber, the coagulation showed remarkable differences, and in some instances has even impressed a name upon the product: nigger heads, bisquits, and sciaps are among the terms applied, but the shape of the crude rubber usually indicates the place from which it is shipped. It will take years to uniformize the rarious native plans adopted for coagulation. Perhaps this will never be accomplished. but on plantations where careful study can be given to the matter it has been determined that heating by smoke produces the cleanest and purest rubber for commercial export.

Rubber is rubber, whether from a tree on the Imazon, in the uplands of Ceara, the mountains of Bolivia, the jungles of Nicaragua, the fastnesses of the Congo, the cultivated plantations of Ceylon, or the northern regions of Mexico: the important question is, however, whether the plant has an abundant yield of latex. Therefore the sonrce of supply has been the subject of great study for the botanist erer since the first American discorerers saw the curious balls and bottles of the natives.

The classification of rubber-bearing trees carries the number well towarl one hundred, and if many latex-producting shrubs and rines 


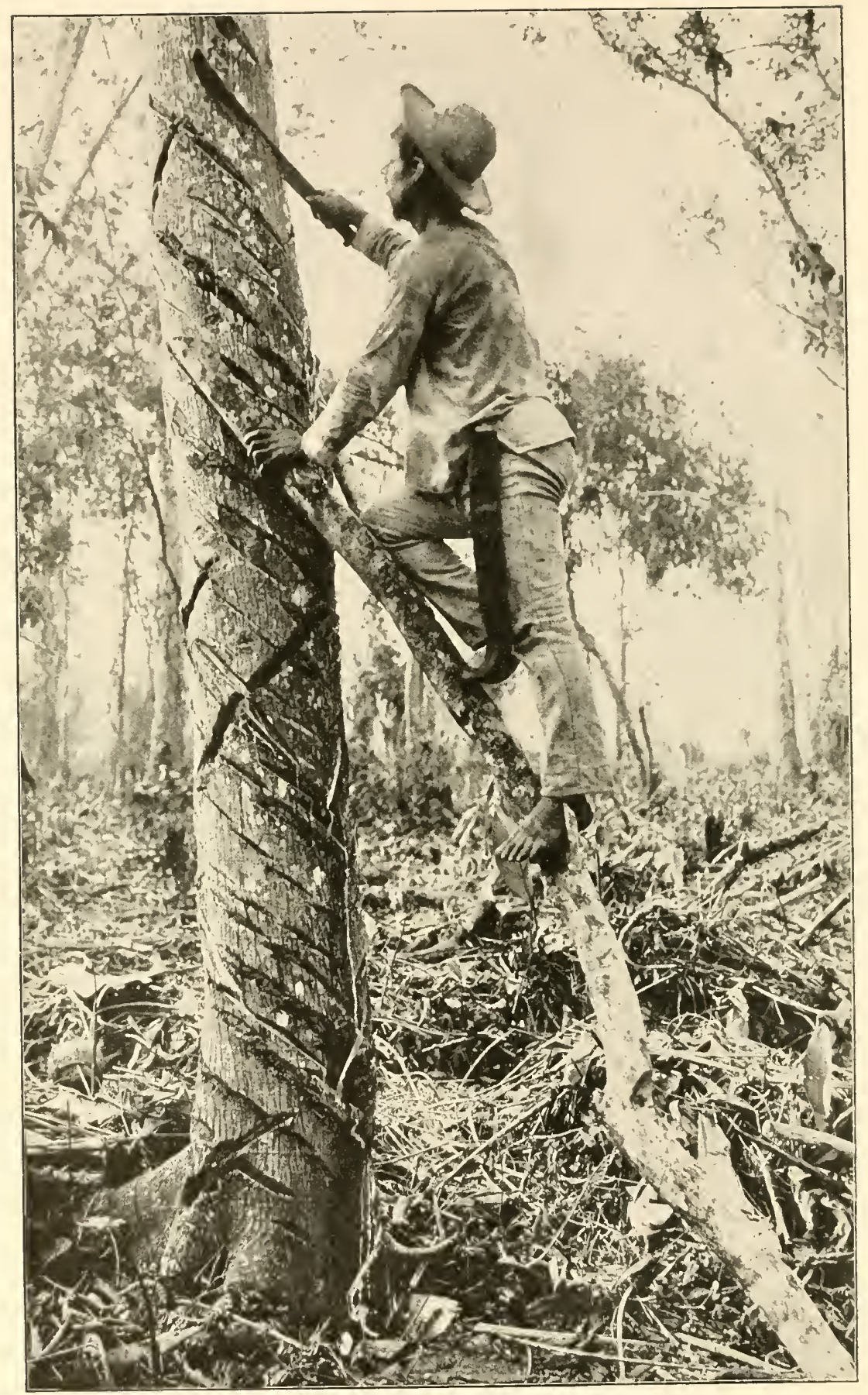

TAPPING A RUBBER TREE IN CHIAPAS, MEXICO.

The object in rubber tapping is not merely to avoid the destruction of trees, but to secure the maximum quanticy of gum with the least injury to future productivenes.

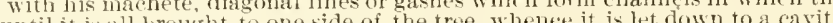
chese are dexterously lifted up. and the milk joured into a calibash or other ressel and carried a way to be coagulated. 
are inchuded, the tale might be made threefold, but for practical purposes only four great species are recognized. The Euphorbiacea contain the Herea and the Manihot; the Ulmaces, the Castillon and the Ficus; the Apocynacer. the IIancomia and the Landolphia; the Asclepiadex, Cynanchum. The six important trees are those under the first three rarieties.

Hever is the rubber tree par excellence. It is indigenons to the region of the river Amazon, and is therefore found thronghont that immense watershed in the tributary areas of Peru. Bolivia. Ecuador, Colombia, and Venezuela. Hevea is a large tree, of comparatively

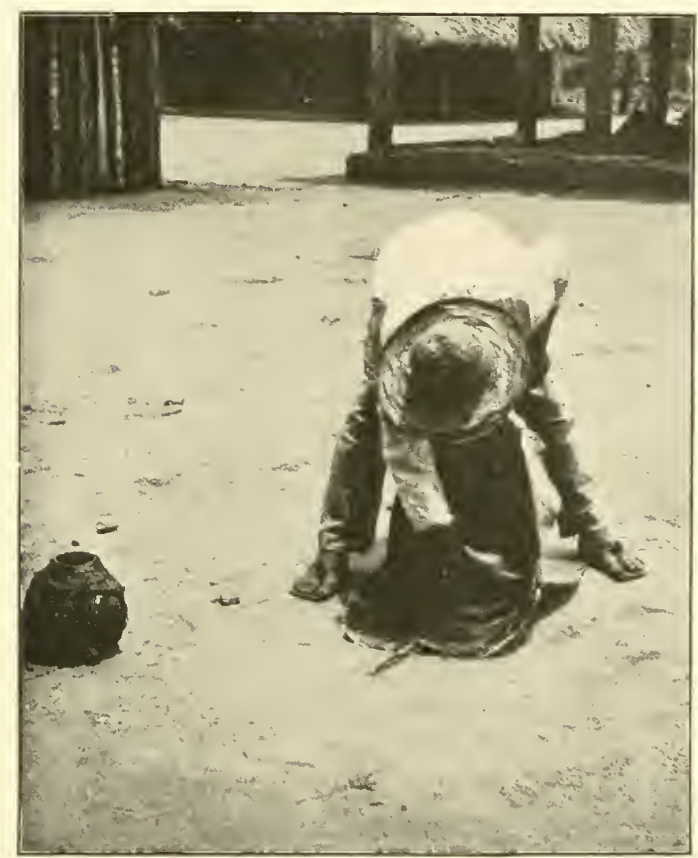

3

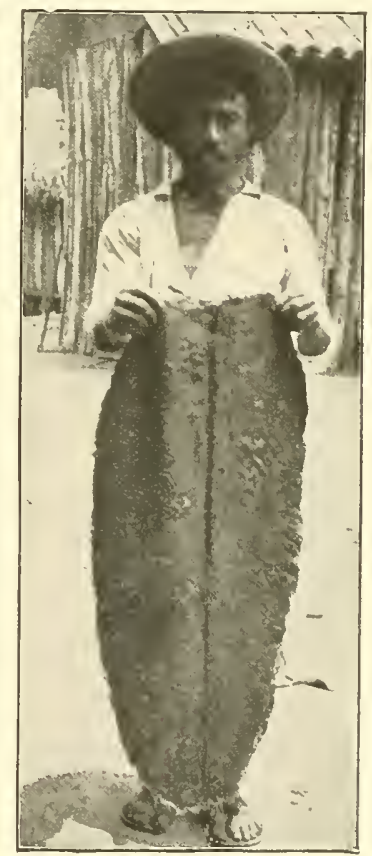

4

COAGULATING THE LATEX IN MEXICO.

3. Stripping the leaves from the rubber. 4. A finished sample of rubler, marked by the veins of the leaves.

slow growth, but on that account of long life. From the fourth rear on it will yield its milk. and may be systematically tapped for twenty years or longer. It is often found 12 feet in circumference, and the seattered trees in the tropic jungle will constitute a forest by themselves. The Herea requires a low-lying, rich, deep soil, with such abundant moisture as only the equatorial neighborhood can give. Hered does not need to be overflowed; in fact. those trees that are subjected to periodic floods near the great rivers are not necessarily the best stock or the largest producer's. Hevea also is well aldipted to cultivation wherever the soil and climate are suitable, and the consensus of opinion is that in the ultimate future this tree. modified 
perhaps by scientific horticulture, will be the chief rubber bearer of commere. This is the tree that has made Brazilian rubber famons, and for generations to come Brazil is assured of a steady somrce of revome from the supply furnished by this native of her fluvial forests.

The Munihot tree produces the Ceara rubber of commerce. Its mative locality is a high. stony, arid, and in places semidesert comnur. Its latex yields a rubber remarkable for strength and tenacity,

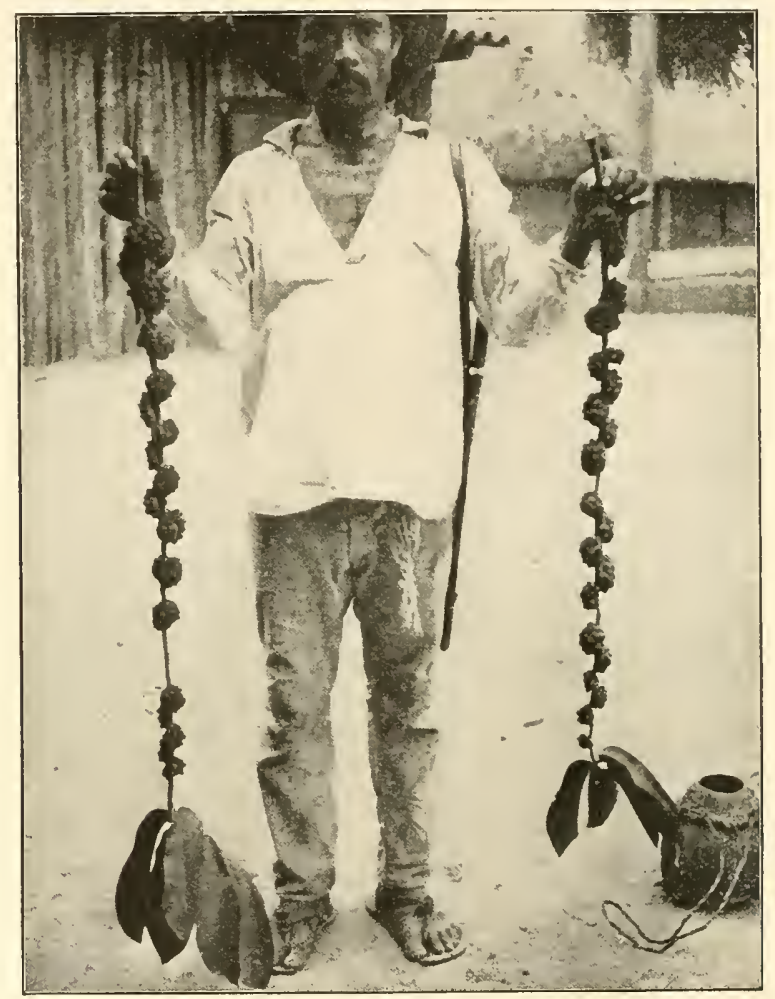

BRANCIIES OF CASTILLOA ELASTICA WITH RIPE FRUIT.

The fruit of the rubber tree has a faintly sweetish taste, but is withont appreciable flavor. It contains cousiderable milk, though not in commercial quantities.

ancl promises to react successfully to cultivation if proper soil is selected for it, but as yet no efforts on a scale large enough for a thorongh test have been attempted.

The C'astilloa, next to the IIevea, is the best-known rubber producer in the rropic belt. Its native habitat is Central America and southern Mexico, and it is foumd in Eenalor. Colombia, and Peru, having been acclimatized also in the West Indies. The tree has at- 


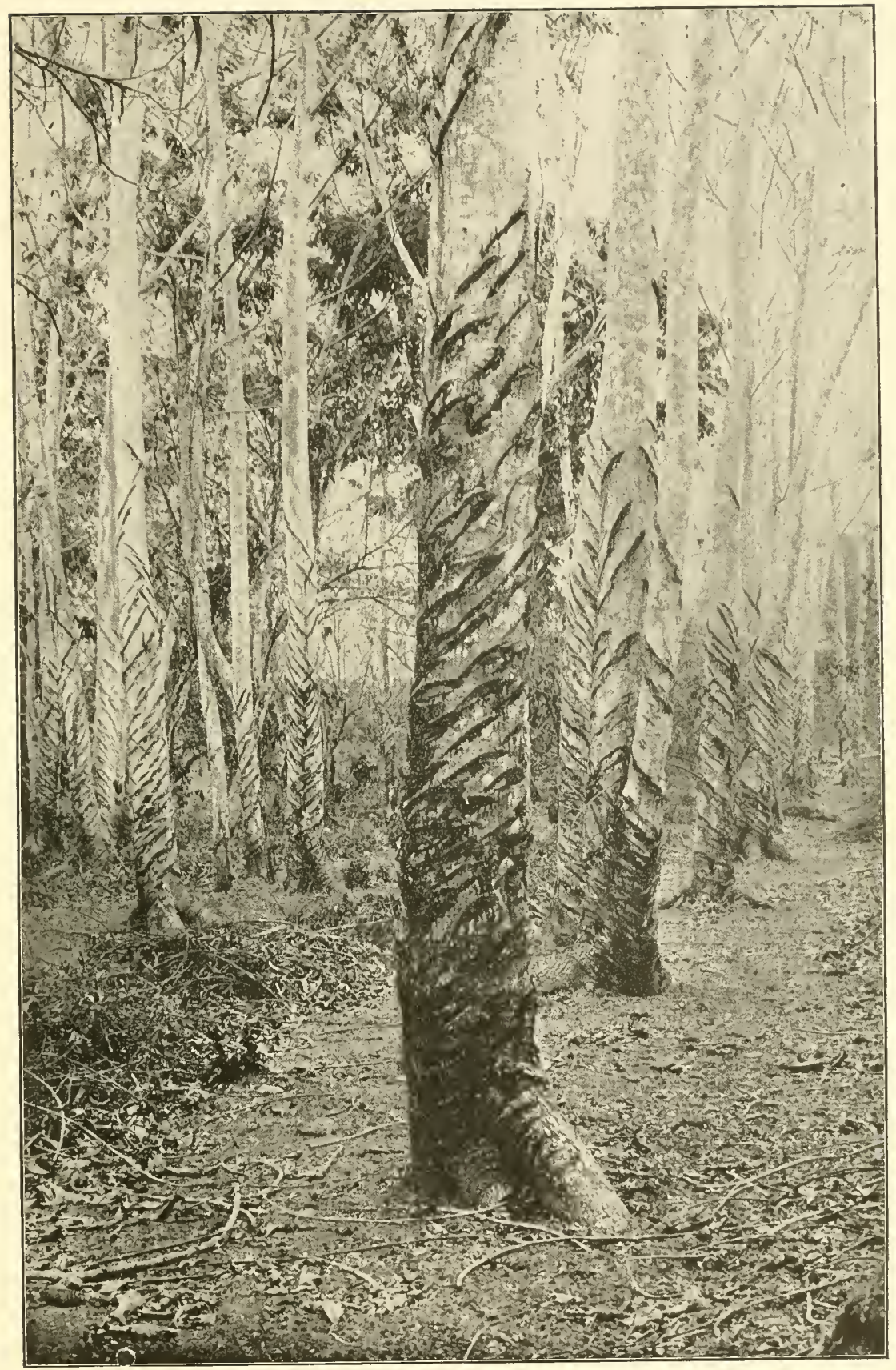

PLANTED CASTILLOA ELASTICA TREES, ABOUT 14 YEARS OLD.

This is a portion of a cultivated grove at La Zacualpa Plantation, Chiapas, Mexico. The searred trunks show that they have been tapped many times. The trees average about a foot in diamcacao, but this has mostly disapreared. 
tracted considerable attention since the exploitation of rubber plantations in the zones north of the equator, and is rery adaptable to cultivation if carefully treated. It is not so large as the Heved, nor is the latex the same, needing therefore quite diflerent treatment in its coagulation; but that is a matter of science and art, which will be regulated as its characteristics becone better known. This is the rubber tree that has been so butchered to supply the growing demands of a consuming world. The natives, in their primitive zeal to extract the greatest possible amount of juice in the shortest possible time, simply felled-killed-the tree and bled it to the last drop. Whole forests have been laid waste in the unrestrained search for muber, but nowadays the principle of conservation has become firmly rooted and the tree must he well treated wherever it is still alive, while cultivation is restoring it to areas originally favorable to its propagation. The Ficus, the rubber tree of urban conservatories, is of the same genus with the Castillou, but its native habitat is the jungle of the eastern 'Tropies. In Issam, New Guinea, and the Malay Islands it is at home, but seems not to be of great profit when cultivated. It is likewise a tree of age, not coming to substantial yield mutil after many years of life. and therefore unpromising to the proprietors of a mbber plantation,

Mlancomile is almost a shrull. It grows sonth of the Amazon Valley, and is found also in Venezuela and Peru; in fact, it is one of the best-known somers of Permvian rubber. It has, howerer, one fatal defect when considered as a plant for future usefulness: in order to get the latex the tree must be cut down. Although more intimate acepuintance may determine that IIencomia can be cultivated. and, acknowledging that its muber product ranks well up in the scale, it is probable that the area in which the tree now grows. if the culture be contimed, will be planted with IIerea or C'astilloa, according to the soil.

Landolphia (Lianas) is a rubber-yielding vine growing in the jungles of the Far East, of New Guinea, and especially of Ifrica in the basin of the Congo. Its produet is commercially of decided value, lunt the fear that it may depress the native industry of Latin America or the cultivated plantations of Ceylon is gromdless, because, however extensive may be the territory over which the vine is found, it must be destroyed in order to extract the latex; and cultivation is out of the question, since the vine requires the smpport of forest trees for its growth. and no plantation ean first cultivate a sunless jungle before introducing a commercial staple. When the indigenoms vine becones exhansted the land on which it appeared must be diverted to other crops. 
Considering the immense and increasing use of rnbber in modern life, it is a fascinating problem to estimate how great may be the rubber-producing area of the world. It can be assumed that the gemuine rubber tree will not repay the eost of cultivation ontside of a

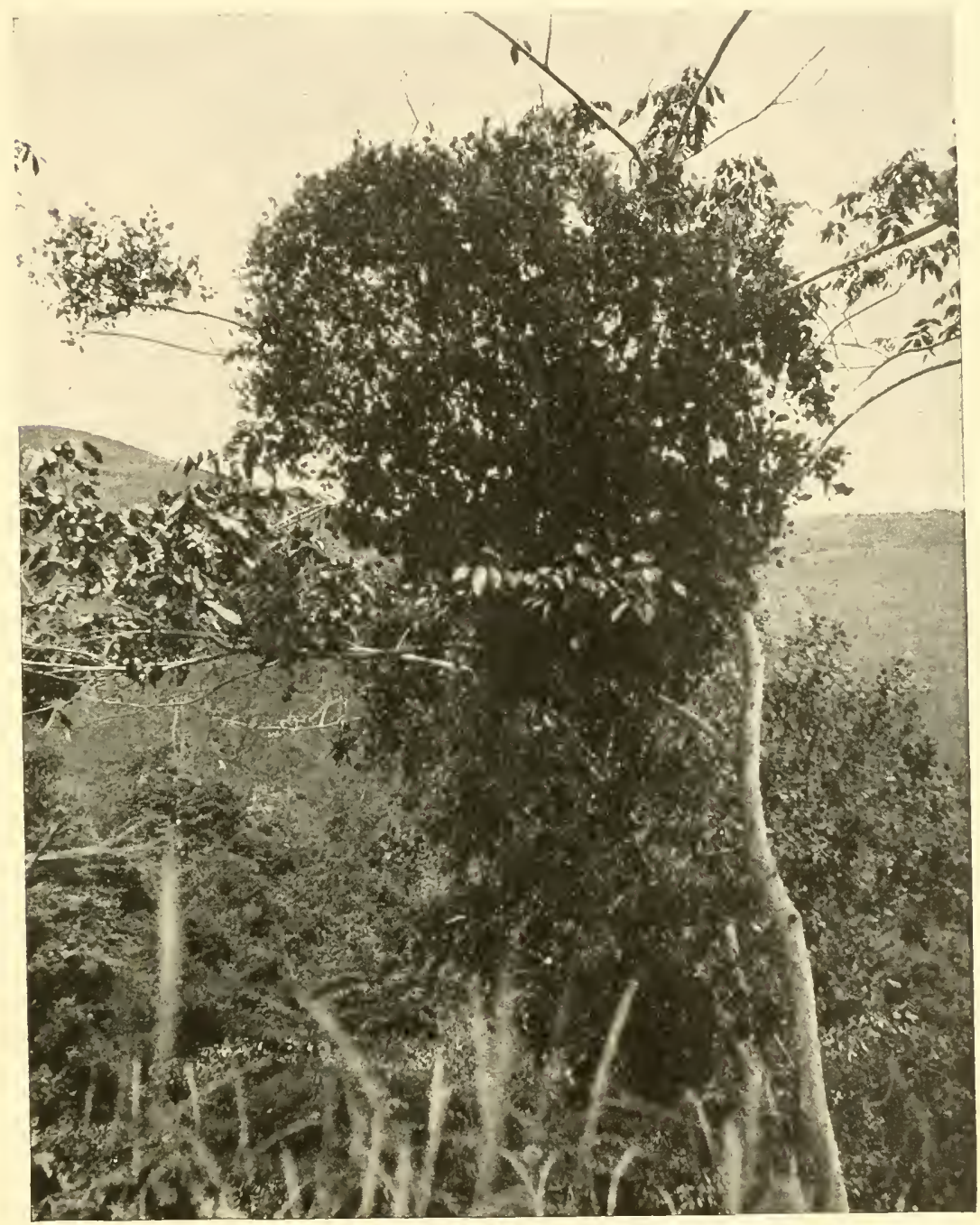

A RUBBER-PRODUCING MISTLETOE IN VENEZUELA.

Though not yielding a commereial rubber, this parasitical growth, like many leguminous plants and shrubs in tropical countries, produces a gummy exudation very similar to good rubber, but lacking the essential property of elasticity.

zone lying about 500 miles on either side of the equator. This includes all the Amazon basin in Brazil, the greater portion of Peru, the northern section of Bolivia, all of Ecuador. Colombia, Venezuela, Panama. Central America, and the southern section of Mexico. In 
Africa it includes the Congo basin and the Sudan on the west, and the analogons portion on the east; in Asia the larger part of India. the northern tip of Australia, the intervening archipelagoes, and the Philippine Islands. No one can calculate with precision the productive extent of these regions, becanse the deciding factors of

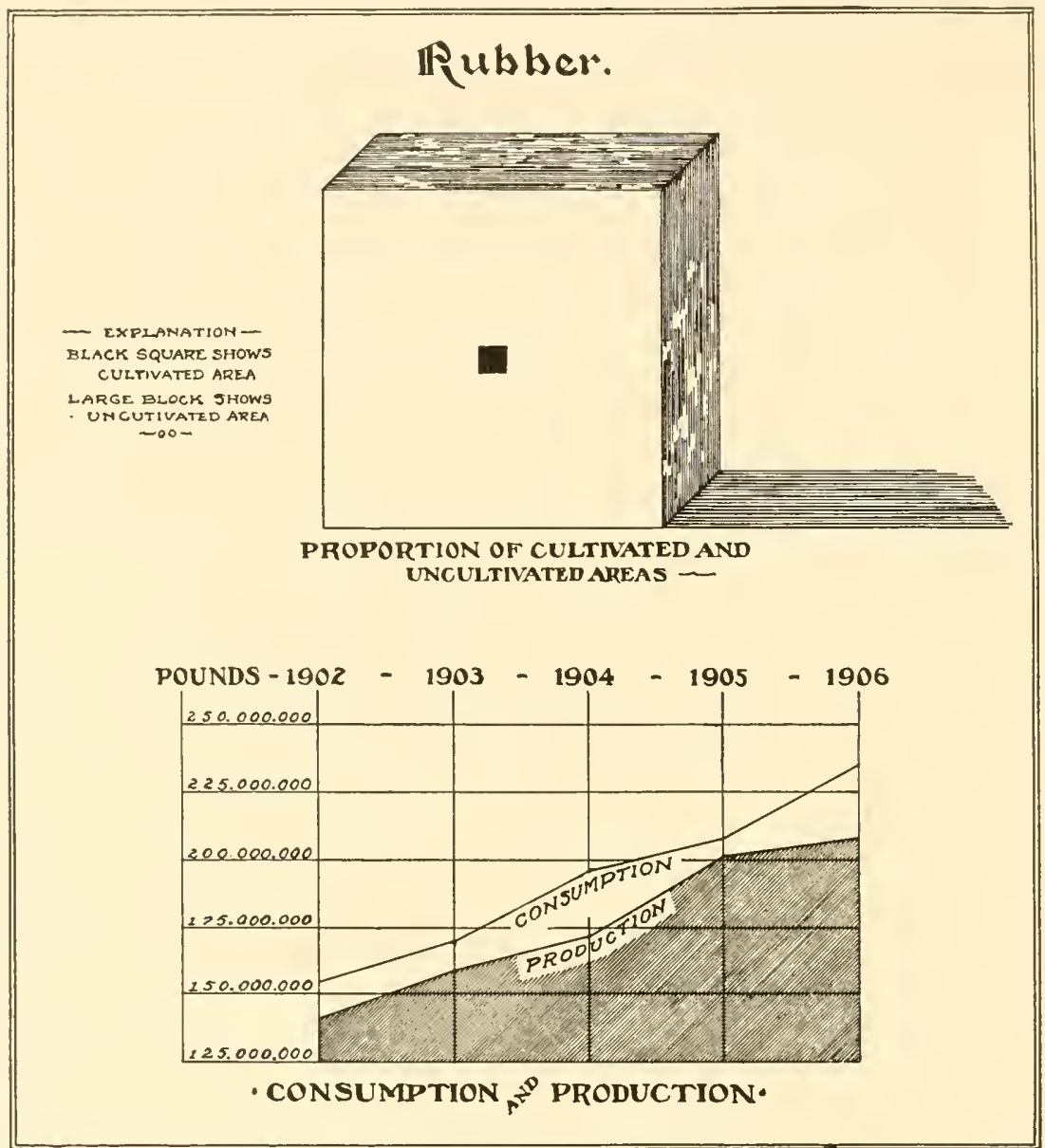

T. $\mathbf{P}$ A.R

NOTE.-Consumption and production are here taken as synonymous with importsand exports, because practically no producing country manufactures rubber, and no consuming country has rubber lands. It is impossible, likewise, to make imports and exports balance, and this explains the continued preponderunce of consumption over production. As a matter of fact, this relationship. although actually maintained, is less than the diagram indicates, because a noticeable amount of reclaimed rubber is annually added to the new rubber just entering the market.

soil. rainfall, elevation, drainage, moisture, and temperature are not enough known; nevertheless, the area absolutely a vailable is so well understood that any fear of a rubber famine, so far as nature's ability is concerned. is unfounded. Rubber cultivation has already extended over 150,000 acres in Ceylon; in the Federated Malay States are 
130,000 acres; elsewhere in the East are at least 30,000 more; so that, even where it has been artificially introduced into an alien land, all told perhaps 600.000 acres, the tree itself is doing its duty in supplying the wants of mankind. In the western continent, Mexico and Central America are extending the cultivated territory for the plant, while experiments are making in other parts of the world. In Cuba and the Philippines there are extensive sections adapted, in all security, to the propagation of rubber. Cultivation, therefore, if con-

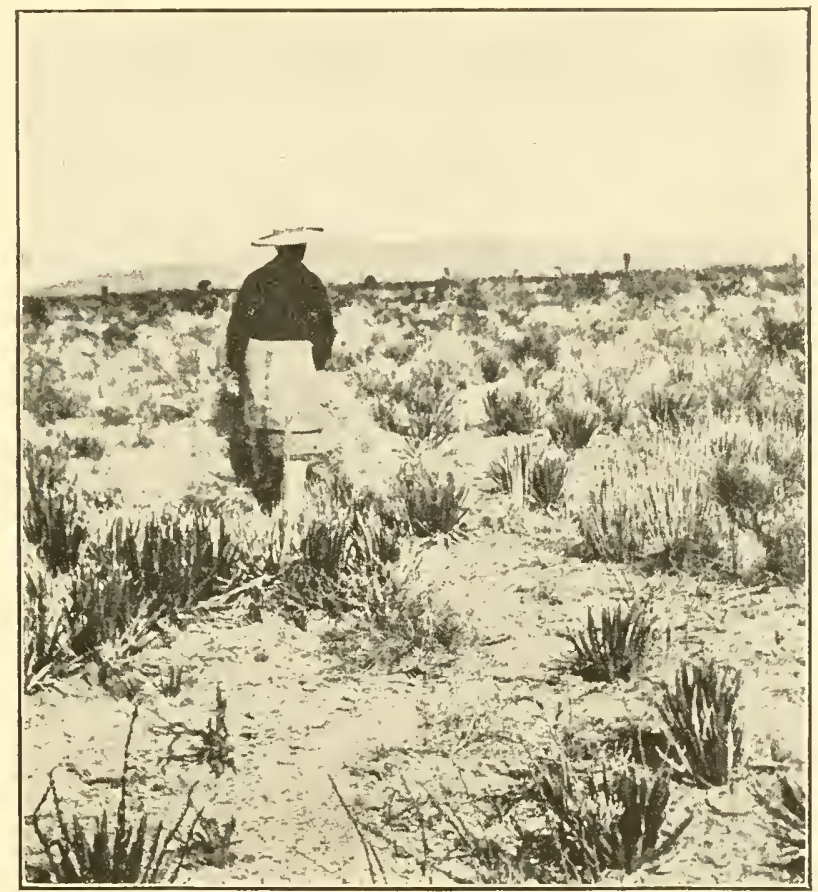

(Reprodueed from India Kubber World.)

AN EXI'ANSE OF GUAYULE LAND.

The guayule shrub is found over large areas of the chaparrales, or bush prairies, in the northern part of the Iexiean highlands. The first reports concerning this plant and its value are said to have been made by a Jesuit priest, about the middle of the eighteenth century. The name is probably derived from the Spanish word IIay (there is), and the lndian word Hule, meaning india-rubber.

ducted scientifically, can furnish the supply. It is not intended to ignore the future productive possibilities of the native forests. In Mexico and Central Ameriea the rubber zone is, from the configuration of the country, within reach: but in the Amazon Valley thousands of square miles are hidden beneath the virgin forest, and however inexhaustible the growth of the tree, the acquisition of the rubber, diflicult at present, will become more and more so as time goes on. That this is the natural habitat of the Hevea can not be doubted, but 
that it will contime to remain the principal somce of supply has been quewtioned by students and ob-ervers ever since Ceylon made a successful plantation of this tree in 18\%. The Brazilian and other governments are earnestly striving to conserve the rubber forests, to rectify earlier mistakes in the way of unrestrained robbery, and to encourage not only the entrance of more capital into the industry, but to bring into cultivation and make more accessible the area already exploited. Nerertheless, it is not beyond possibility that in this in-

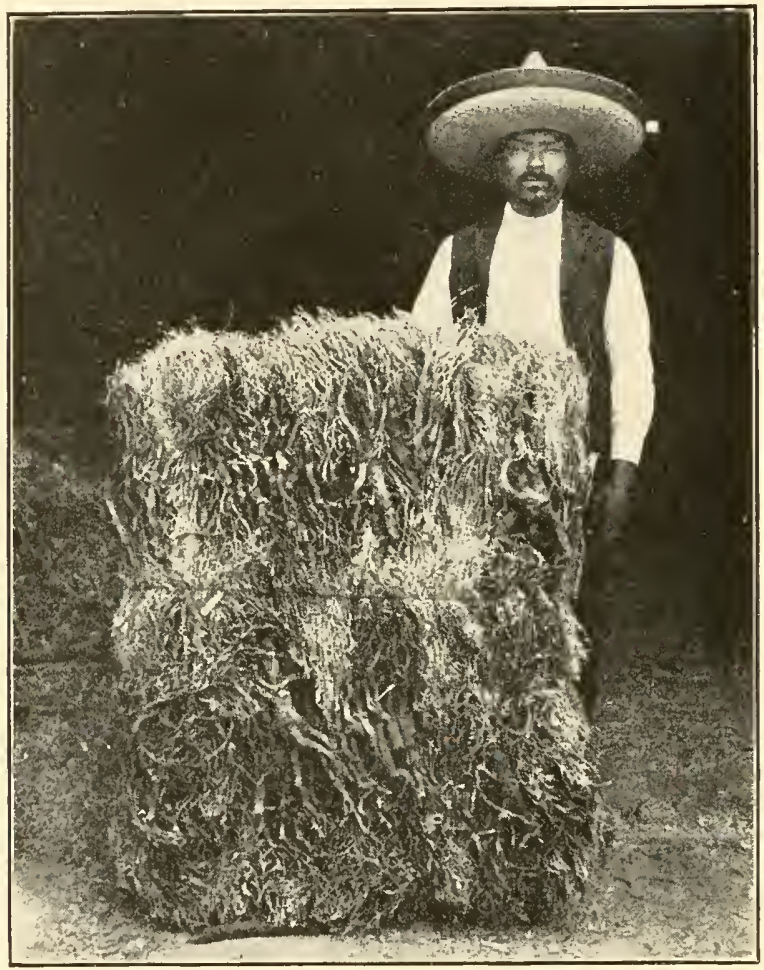

(Reproduced from 1ndia kubber World.)

A BALE OF GUAYULE SHRUB.

Within the few years since the exploitation of the guayule plant began, Mexieo has arisen to second place among the rubber-producing countries of the world. The United States takes 80 per cent of the annual production.

stance the same result may happen as dirl happen with cinchona. This is still known to the pharmacopoia as Peruvian bark, but the industry has moved thousands of miles away from its native birthplace, and the supply of quinine, as far as the commercial market is concerned, now comes from India.

Be all this as it may, Brazil-Manaos, Pará, Ceara-continues to dominate the india-rubber world. Assuming the world's last an- 
nual crop to be $150,000,000$ pounds, her exports in 1907 were over $80,000,000$ pounds. Add to this the Peruvian and Bolivian crops coming down the Amazon, and considering that fine Pará sets the price, it will be seen that many years must pass before the predominance can be overcome. This product was sent to the United States, Great Britain, France, Germany, Uruguay, Belgium, and Argentina, in this order. It is easy to moderstand that Belgium ranks low in importation from Brazil, becanse the output from the Congo has its chief entrepot in Antwerp. The markets for the world's crop may be arranged as follows: The United States, Great Britain, Germany, France, and Belginm.

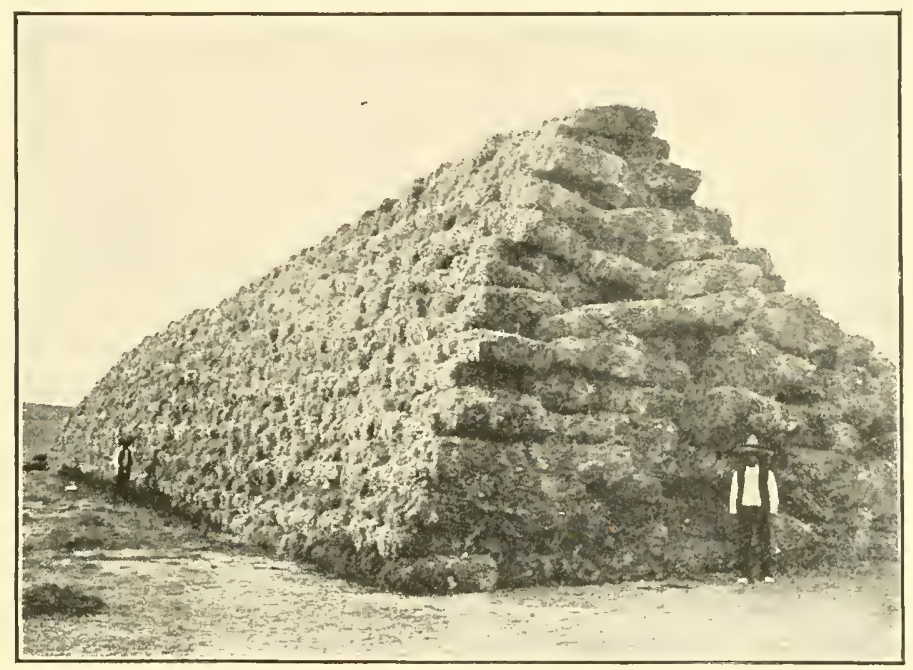

(Reproduced from India Rubber World.)

FOUR IIUNDRED TONS OF GUAYCLE RUBBER.

These bales vary in weight from 70 to 1 " pounds. During the ealendar year 1907 guayule rubber exports from Ifexico reached a total of $11,900,000$ pounds, and for the first six months of 1908 nearly $7,000,000$ pounds.

Guayule is a shrub containing rubber in its branches, but this rubber is pure rubber and can be used for every purpose to which the latex of the Heven is applied. Guayule therefore contradicts the statement made that no rubber conld be produced outside the tropic zone. Guayule is a native of Mexico, but its habitat stretches also well into Texas. The shrub must be destroyed before the juice is extracted, and coagulation must be conducted by a different method, but in the end the outcome is rubber. The business of gathering the plant has become quite snccessful, and it is probable that efforts to cultivate it will turn ont likewise. Gutta percha is not rubber; it was at first confused with the latter, although it had no 
suppleness or elasticity, and its source of origin is a tree related to the india-rubber genus, but physically it has diflerent properties, and in the arts it has different uses. About all the gutta percha of commerce comes from the Far East. Butata is an American gutta percha, growing in many parts of the Tropies, but produced chiefly in Veneznela and the Guianas. A practical distinction between rubber and gutta is found in the (Latin) names, grmmicum elastion for rubber and gumminum plasticum for gutta. This substance has two important uses; one is for insulation in telegraph instruments. but particularly for covering to submarine cables. which it protects better than any known substance against the water or the animal attacks beneath the surface; the second is for forming molds of rarions kinds by surgeons and dentists. It plays also a part in the manufacture of golf balls. It least 1,000 tons a year of gutta percha have been used since 1855 in submarine cables, the length of which has reached over 200,000 miles.

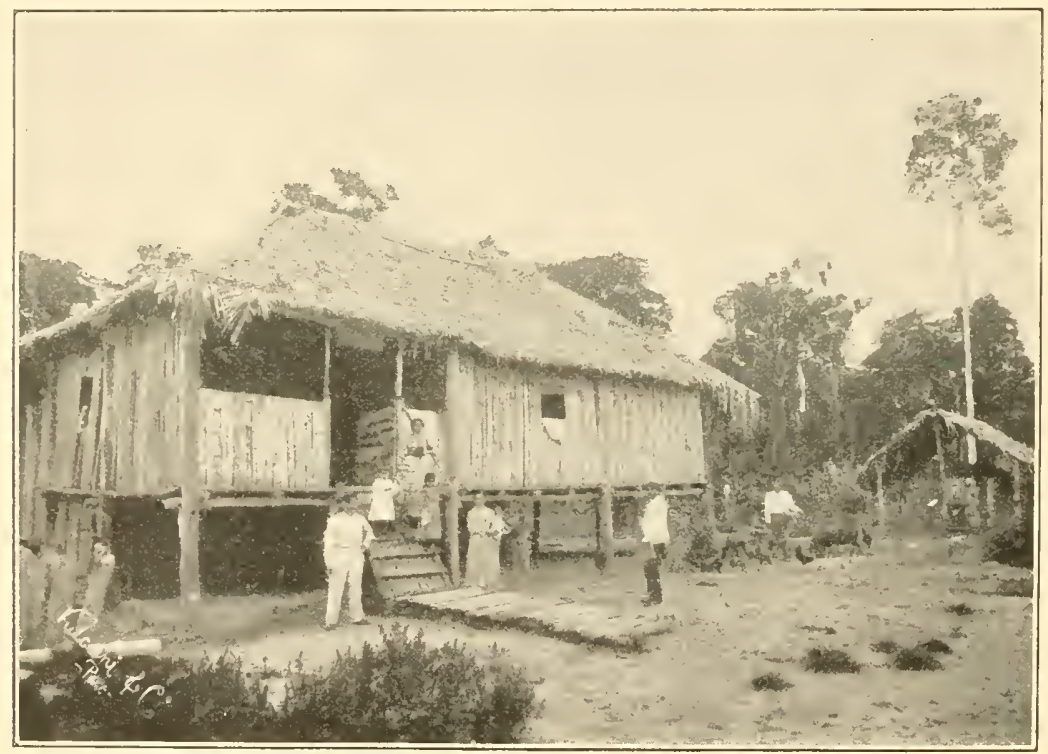

RULBER G.THERER'S IIOME ON TIIE UPPEI AMIZON HIVER. 


